\title{
Wildlife and Wild Places in Mozambique
}

\section{K. L. Tinley, A. J. Rosinha, José L. P. Lobão Tello and T.P. Dutton}

This account of the national parks, reserves and other places worthy of protection in Mozambique gives some idea of the wealth of wildlife in this newly independent country. One special reserve has 25,000 buffaloes-the largest concentration in the world.

Protected conservation areas in Mozambique fall into six categories:

1. Parques nacionais - national parks;

2. Reservas especiais - special game reserves;

3. Reservas parciais - partial reserves;

4. Regimen de vigilancia - fauna protection zones;

5. Coutadas - hunting and photographic safari areas, normally run on a private concession basis;

6. Reservas florestais - forest reserves.

Some unique areas are still outside this system but have been recommended for inclusion, together with other ecosystems worthy of inclusion in the future.

Game farming or ranching is attracting considerable interest; one private and one government scheme have been proposed.

\section{NATIONAL PARKS}

1.* Parque Nacional da Gorongosa (c. $3770 \mathrm{sq} \mathrm{km}$ ). Situated at the southern limit of the great rift valley with an extensive flood plain and associated lakes, this park includes Brachystegia woodland Acacia and Combretum savanna. Sharply rising inselbergs (volcanic protrusions) are also a feature. The ungulates are typical floodplain species, including elephant (abundant), buffalo, wildebeest, waterbuck, zebra, reedbuck, impala and oribi; on the elevated woodland and savanna habitat there are black rhino, eland, Lichtenstein's hartebeest, sable, kudu, nyala, Sharpe's grysbok, suni, blue and grey duiker, and klipspringer are common on rock outcrops; lion, leopard and hippopotamus are abundant. Both land and water birds are prolific and diverse, and crocodiles are very common.

2. Parque Nacional de Zinave (c. $5000 \mathrm{sq} \mathrm{km}$ ). This park represents an important faunistic and floristic transitional zone between moist tropical and arid tropical environments. Brachystegia species and mopani (Colophospermum mopane), Acacia, Combretum tree savanna and sandy grasslands are the major vegetation types. The Save river which forms the northern boundary of the park also marks the northern distribution limit of the southern African race of giraffe and spring hare. A diverse population of

* The numbers refer to the map. 


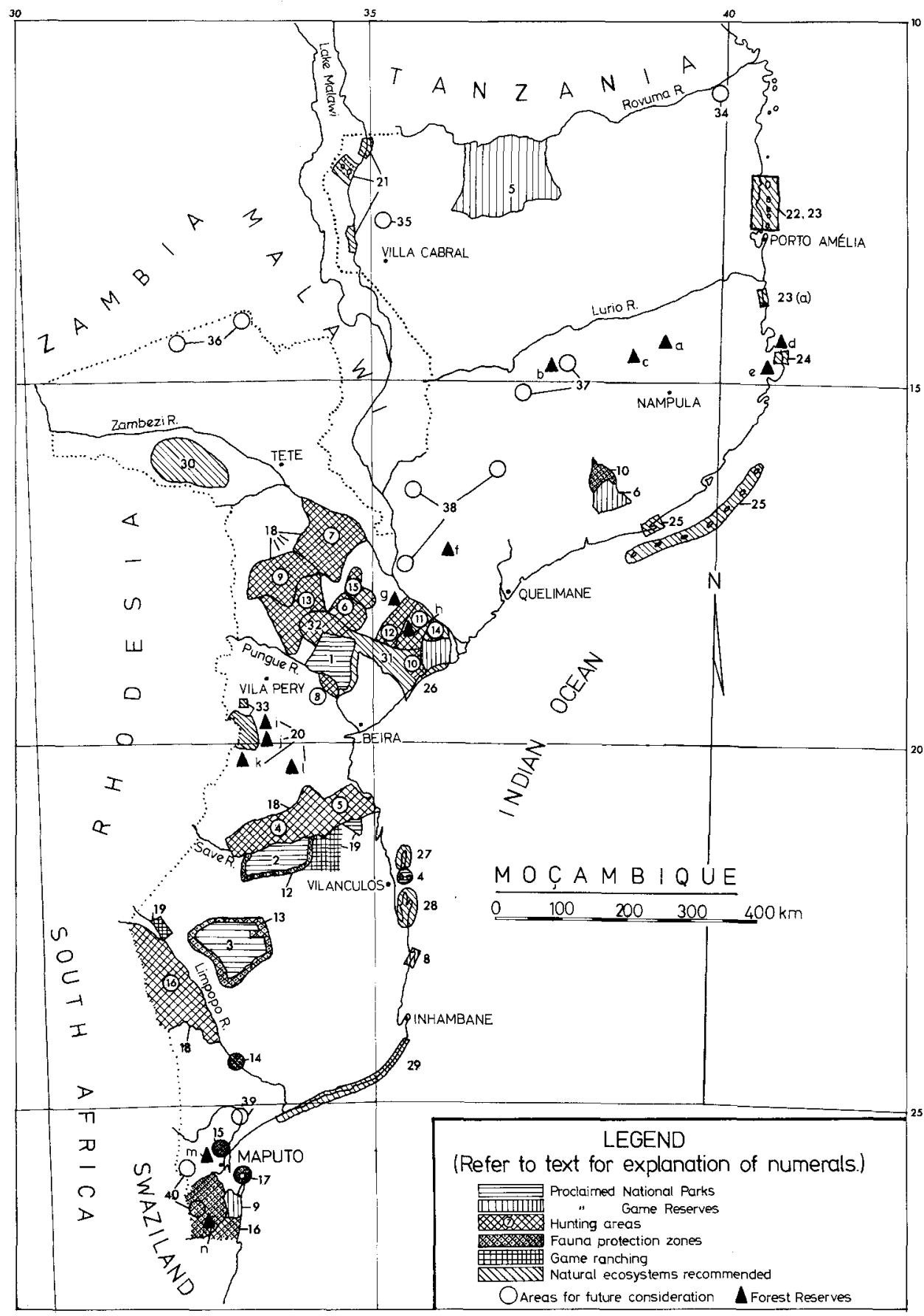


large ungulates includes roan antelope and probably the largest concentration of nyala in Africa. Ostrich and giraffe occur in reasonable numbers, and five species endangered in Mozambique are here: giraffe, roan, caracal, brown hyena, black-backed jackal and cheetah.

3. Parque Nacional de Banhine (c. 7000 sq km). Representing Mozambique's most arid zone (less than $400 \mathrm{~mm}$ rainfall), this park's main feature is open grassland plains with slightly elevated islands where there are baobab Adamsonia digitata, mopani marula Schlerocarva caffra and Terminalia species. The wildlife includes elephant, giraffe, roan antelope, sable, brown hyena, black- and side-striped jackal, caracal, cheetah, small spotted genet and bat-eared fox. Arid-zone birds include ostrich, kori bustard and buffalo weaver. Tsessebe, formerly abundant, are probably now extinct.

4. Parque Nacional do Bazaruto (c. $80 \mathrm{sq} \mathrm{km}$ ). This park is on Ilha (island) Santo Antonio, about ten kilometres off the Mozambique coast near Vilanculos, which was once part of the Santo Sebastian peninsula. There are extensive coral formations, and dugong and five species of marine turtle are found; terrestrial habitats support samango monkey and red bush duiker.

\section{GAME RESERVES Reservas de Caca}

5. Reserva Parcial do Rovuma (c. 15,000 sq km). In this reserve Brachystegia spp. and Baikiaea spp. are the dominant vegetation types, intersected by numerous rivers and associated dambos (open grass plains within the miombo). Unique ungulates include Johnstone's wildebeest and Johnstone's impala; there are elephant, buffalo, black rhino and eland, and Lichtenstein's hartebeest, sable, lion and leopard are abundant.

6. Reserva Parcial do Gile (c. $2100 \mathrm{sq} \mathrm{km}$ ). The dominant vegetation type here is Brachystegia miombo with dambos and numerous rivers. Inselberg protrusions occur, some with endemic Cycadacae. Apart from impala, the fauna is similar to that of Rovuma. The flying squirrel or scalytail, which does not extend south of the Zambezi, is a common crepuscular animal of woodland and riverine habitats.

7. Reserva Especial de Proteç̧ão dos Bufalos de Marromeu (c. $1500 \mathrm{sq} \mathrm{km}$ ). Situated in the southern section of the Zambezi river delta, with floodplain grasslands and forest savanna mosaics on the higher ground (Tinley 1969), this reserve has the largest concentrations of buffalo in the world - about 25,000 animals (Tinley and Dutton 1972). Reedbuck, waterbuck, zebra, sable, Lichtenstein's hartebeest, red duiker and leopard are abundant, and elephant, hippo and lion occur in pleasing numbers. Water birds are abundant and diverse, and include a large nesting colony of white pelicans.

8. Reserva de Pomene (c. $200 \mathrm{sq} \mathrm{km}$ ). Part of the coastal littoral, this reserve has dune forest acid, grasslands, mangrove swamps and associated estuarine environment. Dugong, dolphin and five species of marine turtles occur offshore, and the sea-birds are a feature, but red duiker, samango monkey and chacma baboon are the only major terrestrial fauna. Sable, Lichtenstein's hartebeest, and tsessebe were formerly recorded, and plans for their reintroduction are being considered. 
9. Reserva Especial do Maputo (c. $700 \mathrm{sq} \mathrm{km}$ ). This coastal area has a great variety of habitats - beach, coastal dune forest, dry forest, swamp forest, freshwater and saline lakes, salinas, flood plain, mangrove forests, sandy open grassland and sand ridges with savanna. The world's southernmost large concentration of elephant, about 300 , occur here, along with reedbuck, bushbuck, Natal red duiker, suni, steenbok, nyala, grey duiker, vervet and samango monkeys and serval, and fair numbers of hippo and crocodile. Two of the five marine turtles, leatherback and loggerhead, nest along the adjoining coast. Some 337 bird species have been recorded including the Stanley bustard and Pel's fishing owl (Tello 1973).

\section{FAUNA PROTECTION AREAS Regimen de Vigilancia}

There are seven of these areas where one or more animal species are protected, while others may be exploited. They are Area do Gilé (10) (refer Reserva Parcial do Gilé), where all wildlife is protected; Troco do Rio Pungue (11), where hippo are protected; Area do Zinave (12), corridor of $5 \mathrm{~km}$ : Area do Banhine (13), a five- $\mathrm{km}$ corridor around the park where all wildlife is protected; Troco do Rio Limpopo (14), at the dam wall, and Area de Marracuene (15) on the Incomati river, both protecting hippo; Area do Maputo (16), extending from the Umbuluzi river to the Maputo river and from the coast to the Libombo mountains, where all animal species are protected - this was deemed necessary after most of the wildlife had been seriously depleted by hunters; and Ilhas da Inhaca e dos Portugueses (17), where some animal species and corals are protected. Corals come under the control of the Instituto Investigacao Cientifico de Moçambique and various port captains.

\section{HUNTING AND SAFARI AREAS Coutadas (c. 54,000 sq km).}

These areas are normally leased out to private enterprise for controlled hunting for trophy animals and more recently for photographic or biological safaris. Four are in the district of Chimoio (4, 7, 9 and 13), eight in the District of Beira $(5,6,8,10,11,12,14,15)$, and one is in the District of Gaza (16). Four have been deproclaimed $(1,2,3,17)$.

\section{GAME RANCHES AND GAME FARMS (19)}

Interest is being aroused in the creation of multipurpose wildlife resource-use areas, especially those with fragile substrates, vegetative cover and tsetse fly Glossina morsitans. The Upper Limpopo area still has a diverse and varied spectrum of wildlife together with attractive scenery. In the south-east section of the Save River most of the wildlife has been destroyed, but the habitat is still viable and reintroductions are contemplated. Some species such as nyala, hippo and waterbuck can be taken from Zimave National Park.

\section{FOREST RESERVES Reservas florestais (20)}

These 14 reserves fall under the control and protection of the Forestry Department (Direccao dos Servicos de Agricultura e Florestas). They consist of representative examples of unique vegetation types (mainly trees) from 
moist evergreen forest through to woodland, savanna and dry semideciduous forest. Starting in the north these are: a. Mecuburi, b. Ribaue, c. Nepalue, d. Baixo Pinda, e. Matibane, f. Derre, g. Inhamitanga, h. Nhapacue, i. Moribane, j. Zomba, k. Maronga, l. Mucheve, m. Bobole, n. Licuati.

\section{NATURAL ECOSYSTEMS RECOMMENDED FOR PROTECTION}

\section{Coastal Areas}

Three areas on the steep mountainous coast of Lake Malawi (21), where there are few or no inhabitants are recommended; their exact boundaries will be determined by detailed surveys.

Other recommendations are:

Islands of the Quirimba group with unique fringing coral reefs, and exceptionally clear water (22). A preliminary survey was made by Mrs Margaret Smith, Director of the J. L. B. Smith Institute of Ichthyology, in conjunction with the Instituto Investigacao Cientifica Moçambique, and recommendations made;

North side of the bay opposite Porto Amelia (23) where there are coral rock cliffs and coastal thickets of Guibourtia schliebenii;

Area between Nacala and Mossuril including Quitangonba Island, which is an important bird nesting site (24).

Primeira and Segundo Islands (25), where there are exceptional fringing coral reefs and important marine-turtle nesting beaches. The mainland opposite has evergreen moist forest and mangrove forest, and provides a useful starting point for tourist visitors to the islands.

Zambezi delta and Cheringoma coast (26), where exceptional mangrove swamps, freshwater swamps and floodplains support large concentrations of buffalo (see new ecological limits of Parque Nacional da Gorongosa);

Bazaruto Island (27), an important feeding area for dugong and nesting area for marine turtles;

San Sebastian Peninsula (28), Brachystegia coastal savanna, with abundant Cycadacae, marine turtle nesting beaches and a flamingo nesting area.

An area somewhere between Cabo das Correntes and the Limpopo River (29), with unique and unexploited coastal dune forest, and including an adjacent freshwater lake where endemic freshwater fish occur.

\section{Terrestrial Ecosystems}

Parque Nacional de Chioco or Luia (30), south of Cabora Bassa, which is scenically spectacular and supports a diverse although small population of wildlife;

New ecological limits of the Parque Nacional da Gorongosa (31) which will include Serra Gorongosa to the coast, incorporating the Marromeu area.

Mhanda Inselberg (32), west of Serra Gorongosa, where moist evergreen fringing forest is supported by orographic rain created by the Inselberg.

Serra Chimanimani and Serra Maquta (33) have a unique montane flora with no fewer than 46 endemic vascular plants, and also endemic reptiles and amphibia. Elephant, buffalo, sable, eland, bushbuck, blue duiker, klipspringer, reedbuck are some of the ungulates that occur. The lowland moist evergreen forests are largely unexplored and undoubtedly contain interesting faunal and floristic forms. 
Additional natural ecosystems worthy of consideration as conservation areas are:

A unique and faunistically unexplored semi-arid zone (34), with baobab Adansonia digitata, Guibourtia schliebenii and Fernandoa sp. west of Cabo Delgado on approximately longitude $40^{\circ}$. Some interesting forms will undoubtedly be discovered here;

Montane habitats with moist evergreen forest immediately north of Vila Cabral (35);

One of two areas on the northern frontier with Zambia (36), where Brachystegia floribunda and Julbernardia globiflora vegetation types are represented. An interesting associated fauna can be expected;

Inselberg communities between Entre-Rois and Nampula (37), scenically splendid and with an interesting fauna and flora;

Three montane communities near Lugela, Mongoe and Morrumbala (38), with moist evergreen forests and splendid scenery, but largely unknown faunistically. Ilha Mariana in the floodplain of the Incomati river (39), a unique wetland habitat and a vitally important breeding area for waterfowl. There are unusual islands of Pandanus and Raffia palms. Buffalo occurred here in the recent past; a few hippo have survived.

Libombos Mountain Reedbuck Park (40), with viable mountain reedbuck and Sharpe's grysbok habitat, excellent ravine forests and outstanding scenery.

\section{References}

DUTTON, T.P. and DUTTON, E.A.R. 1973. Reconhecimento Preliminar das Montanhas de Chimanimani e Zonas adjacentes com vista, a criacao duma area de conservacao. Report.

DUTTON, T.P. 1973. Reconhecimento da Zona Oriental do Rio Save com vista a criacao de um Posto Piloto de Pecuarizacao de Animais Bravious. Report.

DUTTON, T.P. 1973. Reconhecimento da Concessao de Amilcar Simoes (Juliao) situado na area de Chicualacuala, distrito de Gaza com Vista ao estabelecimento de um esquema de utilizacao das terras, em larga escala, para fims de conservacao. Report.

HUGHES, G. 1971 Sea Turtles. SARCCUS Symposium Parque Nacional da Gorongosa. JAMES, A. 1971. The Gorongosa Reserve, Oryx 11 (2-3), 109-110.

PAISANA, F.D. and ROSINHA, A.J. 1972. Inventariacao dos problemas relacionados com a protecção da Fauna e seu aproveitamento nacional. L.M.

SMITHERS, R.H.N. and LOBAO TELLO, J.L.P. Check List and Atlas of Moçambique Mammals. In prep.

LOBAO TELLO, J.L.P. Apassada e presente distribição dos grandes mamiferos bravios de Moçambique em preparacar. Reconhecimento Ecologico do Zinave 1971, Ciclostilografado do Posto de Estudos Ecologicos do Zinave, arquivos.

1973. Reconhecimento ecologico da Reserva dos elephantes do Maputo. Veterinaria Mocambicana, L.M.

Reports and correspondence in files of Reparticao Tecnica da Fauna and Safar ilandia Lda.

TINLEY, K.L. 1969. Os Limites ecologicos do Parque Nacional da Gorongosa, Moçambique. Report.

1971. The conservation of ecosystems and tourist impact upon these and their custodians. SARCCUS Parque Nacional da Gorongosa.

1971. Determinants of coastal conservation dynamics and diversity of the environment as exemplified by the Moçambique coast. SARCCUS Parque Nacional da Gorongosa. Sketch of Gorongosa National Park Moçambique. SARCCUS Parque Nacional da Gorongosa. 1974. Priority studies. Report to the Reparticao da Fauna L.M.

TRAVASSOS SANTOS DIAS, J.A. and ROSINHA, A.J. 1971. Proposta para a criacao do Parque Nacional do Banhine. Universidade de Lourenço Marques.

TRAVASSOS SANTOS DIAS, J.A. 1971. Proposta para Criacao da Reserva de Caca de Zinave. Universidade de Lourenço Marques. 
Mammals, Birds and Reptiles

Flying or Scaly-tailed squirrel

Spring hare

Chacma baboon

Samango monkey

Vervet monkey

Side-striped jackal

Black-backed jackal

Bat-eared fox

Small-spotted genet

Brown hyena

Serval

Caracal

Lion

Leopard

Cheetah

Dugong

Elephant

Burchell's zebra

Black rhinoceros

Hippopotamus

Giraffe

Eland

Kudu

Nyala

Common waterbuck

Southern reedbuck

Lichtenstein's hartebeest

Tsessebe

Wildebeest

Impala

Red bush duiker

Blue duiker

Grey duiker

Oribi

Suni

Klipspringer

Steenbok

Sharpe's grysbok

Buffalo

Roan antelope

Sable antelope

White pelican

Kori bustard

Stanley bustard

Pel's fishing owl

Loggerhead turtle

Leatherback turtle

Nile crocodile
Anomalurus derbianus

Pedetes capensis

Papio ursinus

Cercopithecus labiatus

C. aethiops

Canis adustus

C. mesomelas

Otocyon megalotis

Genetta genetta

Hyaena brunnea

Felis serval

F. caracal

Panthera leo

$P$. pardus

Acinonyx jubatus

Dugong dugon

Loxodonta africana

Equus burchelli

Diceros bicornis

Hippopotamus amphibius

Giraffa camelopardalis

Taurotragus oryx

Tragelaphus strepsiceros

T. angasi

Kobus ellipsiprymnus

Redunca arundinum

Alcelaphus lichtensteini

Damaliscus lunatus

Connochaetes taurinus

Aepyceros melampus

Cephalophus natalensis

C. monticola

Sylvicapra grimmia

Ourebia ourebi

Nesotragus moschatus

Oreotragus oreotragus

Raphicerus campestris

$R$. sharpei

Syncerus caffer

Hippotragus equinus

$H$. niger

Pelecanus onocrotalus

Ardeotis kori

Neotis denhami stanleyi

Scotopelia peli

Caretta caretta

Dermochelys coriacea

Crocodylus niloticus

\section{The Authors}

Dr A. J. Rosinha is Chefe dos Servicos de Proteccao a Fauna; Jose L. P. Lobao Tello is Chefe do Posto de Estudos Ecologicos do Zinave, colaborador do Instituto Investigacao Veterinaria de Moçambique; K. L. Tinley was Ecologist and T. P. Dutton is a Technical Assistant for the Servicos de Proteccao a Fauna. 